\title{
Social Status in Pairs of Male Squirrel Monkeys Determines the Behavioral Response to Central Oxytocin Administration
}

\author{
James T. Winslow and Thomas R. Insel \\ Laboratory of Clinical Science, National Institute of Mental Health, NIHAC, Poolesville, Maryland 20879
}

\begin{abstract}
Oxytocin, when administered centrally, has been associated with the modulation of various social initiatives including maternal and sexual behaviors. The nature of these effects depends on gonadal hormone status. In the present experiments, we investigated the effects of centrally administered oxytocin on the behavior of pair-housed male squirrel monkeys during interactions with a familiar female monkey. Pairs of male squirrel monkeys established reliable and persistent dominance relationships with dominant males showing increased sexual and aggressive behavior as well as higher plasma concentrations of testosterone. Oxytocin $(0.1,1.0$ $\mu \mathrm{g}$ ) increased the sexual and aggressive behavior of dominant monkeys without affecting these measures in the subordinate monkeys. In contrast to these effects in the dominant monkeys, oxytocin increased associative and marking behaviors only in subordinate monkeys. Central administration of the oxytocin receptor antagonist $\mathrm{d}\left(\mathrm{CH}_{2}\right)_{5}\left[\mathrm{Tyr}(\mathrm{Me})^{2}\right.$, $\mathrm{Thr}^{4}$,Tyr- $\mathrm{NH}_{2}{ }^{9}$ ] OVT (OTA; $0.05 \mu \mathrm{g}$ ) had no intrinsic effect on behavior but blocked the effects of exogenous oxytocin. To investigate further the specificity of oxytocin's effects on social behavior, we administered the structurally related peptide arginine vasopressin under identical conditions. Vasopressin $(0.5,5.0 \mu \mathrm{g})$ decreased social behaviors and increased motor activity in both dominant and subordinate monkeys. Previous studies in rodents have demonstrated that oxytocin receptors are induced by gonadal steroids in a regionally specific fashion. The status-related behavioral effects of oxytocin in the squirrel monkey may reflect differences in brain oxytocin receptor density associated with the higher concentrations of testosterone in the dominant animal. Alternatively, the status-related effects may depend on the conditioned behavioral differences associated with social organization.
\end{abstract}

The neurohypophyseal peptide oxytocin (OT) has been shown to affect several aspects of behavior through actions at specific receptors in the CNS. In rats, central administration of OT has been associated with increased grooming (Drago et al., 1986), initiation of maternal (Insel, 1990) and reproductive behaviors (Dornan and Malsbury, 1989), and changes in cognitive per-

Received Nov. 19, 1990; revised Jan. 31, 1991; accepted Feb. 15, 1991.

We wish to thank Manish Kalaria, Kelsey Thompson, and Steve Dinterman for assistance during the data collection phase, as well as Drs. L. E. Shapiro and D. M. Witt for expert readings of the manuscript.

Correspondence should be addressed to James T. Winslow, Ph.D., Laboratory of Clinical Science, P.O. Box 289, NIHAC, Poolesville, MD 20837.

Copyright (C) 1991 Society for Neuroscience 0270-6474/91/112032-07\$03.00/0 formance (Kovacs, 1986). Several recent findings have demonstrated important interactions between gonadal steroids and OT. At a behavioral level, OT's effects on maternal and female sexual behavior require priming with gonadal steroids (Pedersen and Prange, 1979; Fahrbach et al., 1984; Caldwell et al., 1986; Gorzalka and Lester, 1987; Kendrick et al., 1987). At a cellular level, estrogen increases the hypothalamic synthesis of OT (Caldwell et al., 1989; but see also Burbach et al., 1990) and induces oxytocin receptors in discrete limbic nuclei (De Kloet et al., 1986; Insel, 1986; Coirini et al., 1989; Tribollet et al., 1990). Physiologic concentrations of estrogen appear sufficient to induce production of functional OT receptors (Insel, 1986; Pliskin et al., 1989). Similarly, testosterone treatment of castrated male rats increases binding to hypothalamic OT receptors (Johnson et al., 1989), suggesting a potential interaction between testosterone and OT in the control of male sexual behavior.

In the present experiments, the behavioral effects of centrally administered OT were studied in squirrel monkeys. Squirrel monkeys provide an unusual opportunity to investigate the possible interaction of OT and testosterone without exogenous steroid priming because they show consistent, profound differences in plasma testosterone depending on social status (Mendoza et al., 1978; Coe et al., 1985; Winslow and Miczek, 1988). For example, plasma testosterone concentrations in dominant monkeys may range from 2 to 50 times higher than subordinate squirrel monkeys depending on the mating season (Coe et al., 1985; Winslow and Miczek, 1988). These differences are also correlated with different patterns of social, aggressive, and nonsocial behaviors (Coe et al., 1985; Winslow and Miczek, 1988). Squirrel monkeys have also been shown to be differentially sensitive to the effects of a variety of pharmacological and environmental challenges on behavior and physiology, depending on social status (Coe et al., 1979; Miczek and Gold, 1983; Winslow and Miczek, 1985). To determine if the effects of the peptide would be different in dominant and subordinate monkeys, we observed responses in the home social cage of two males and one female. To assess the receptor specificity of the behavioral response to OT, we coadministered the selective OT antagonist

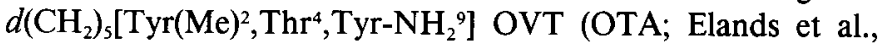
1987). In addition, we studied the effects of the structurally similar neurohypophyseal peptide arginine-vasopressin (AVP). In contrast to the effects on OT, testosterone treatment increases the AVP innervation of certain limbic regions, such as the lateral septum, without affecting receptors (De Vries et al., 1985; Tribollet et al., 1990). Nevertheless, as with OT, behavioral studies have demonstrated that AVP effects on scent marking (in the golden hamster; Albers et al., 1988) and social memory (in the rat) are testosterone dependent (Bluthe et al., 1990). 


\section{Materials and Methods}

Subjects and housing. Eight adult male squirrel monkeys (Saimiri sciureus) of the gothic arch variety and weighing 800-1100 gm were pair housed in a primate vivarium with controlled temperature $\left(30-32^{\circ} \mathrm{C}\right)$ and light cycle (12-hr:12-hr light/dark cycle). Home cages $(60 \times 60 \times$ $152 \mathrm{~cm}$ ) were equipped with free access to food and water and permitted full visual and auditory contact with other pair-housed monkeys. This study was reviewed and approved by the National Institute of Mental Health Animal Care and Use Committee.

Six months after pair housing of male monkeys, individual adult female squirrel monkeys were placed in cages $(60 \times 60 \times 152 \mathrm{~cm})$ immediately adjacent to each pair-housing cage. This arrangement permitted full visual and auditory and limited tactile interactions between cages.

Surgery. Monkeys were anesthetized ( $20 \mathrm{mg} / \mathrm{kg}$, i.p.; Somnifer), placed in a Horsely-Clark stereotaxic instrument, and secured with ear bars and eye pieces. A stainless-steel guide cannula (28 gauge; Plastic Products, Inc., Roanoke, VA) was lowered unilaterally into the lateral ventricle $(10.0 \mathrm{~mm}$ anterior to interaural $0, \pm 2.0 \mathrm{~mm}$ lateral, $10 \mathrm{~mm}$ below dura; Gergen and MacLean, 1962) with placement confirmed by the presence of cerebrospinal fluid in the lumen of the cannula.

Behavioral testing and measurement. Beginning 1 week after females were placed in cages adjacent to pair housed males, doors between the male and female cages were opened to permit free access between cages each morning (0830). Female monkeys were returned to their home cage $3 \mathrm{hr}$ later, and access doors were closed.

Interactions between male and female monkeys in each cage were videotaped for subsequent analysis. Social organization was quantified by measuring aggressive interactions between all three monkeys during the first $30 \mathrm{~min}$ after combination of the male and female cages. Trained observers scored the social and nonsocial behavior of focal monkeys (Altman, 1974) from videotaped records of 15-30-min testing periods. Data were collected on portable computers (Tandy 102, Radio Shack, Inc.) and were subsequently transmitted to an Apple Macintosh for statistical analysis. An exhaustive, mutually exclusive coding strategy was devised. The list of behavioral items was based on the definitions of Hopf et al. (1974) and illustrated in Miczek and Gold (1983). The frequency and duration of elements of associative and aggressive behaviors initiated by and directed at both treated and untreated focal monkeys were recorded. Further elements of social significance included vocalizations and olfactory marking such as urine washing, anogenital washing, anogenital rubbing, back rolling, rubbing chest, back, or muzzle, and sneezing (Hennessey et al., 1978). All incidents of autogrooming, feeding, foraging, walking, stationary alert posture, and sitting with curled tail were also measured.

Blood samples. Blood samples (approximately $1 \mathrm{ml}$ ) were collected between 0830 and 0900 in the morning from the femoral vein of lightly anesthetized monkeys (ketamine, $0.05 \mathrm{ml} / \mathrm{kg}$ ). Monkeys scheduled for blood withdrawal were captured immediately prior to sampling. The capture-to-sample interval averaged less than $5 \mathrm{~min}$. Blood samples were spun for $15 \mathrm{~min}$ at $2000 \times g\left(4^{\circ} \mathrm{C}\right)$. An aliquot of plasma was frozen $\left(-70^{\circ} \mathrm{C}\right)$ for subsequent assay of testosterone using a commercial total testosterone radioimmunoassay (RIA) kit (Coat-a-Coat, Diagnostics Products Corp., Los Angeles, C.A). Assay sensitivity is $0.04 \mathrm{ng} / \mathrm{ml}$. Intra- and interassay coefficients (CV) averaged $2.38 \%$ and $10.83 \%$, respectively. Cross-reactivity with dihydrotestosterone is less than $5 \%$.

Experimental design. Baseline levels of aggressive and sexual behavior, selected to evaluate the stability of social interactions over the course of the entire study, were determined during three phases. Phase 1: prior to capture-adaptation procedures, social interactions of monkey triads were assessed in three weekly observations per male monkey. Phase 2 : beginning 2-3 weeks after cannula implant, male monkeys were captured and restrained, and the threaded stylette cover was removed and replaced at least once per week to adapt animals to the experimental protocol; doors separating males and females were opened, and measures of group interactions were collected for $15 \mathrm{~min}$ beginning $15 \mathrm{~min}$ after returning male monkeys to their home cage. This phase continued until a stable baseline of aggressive and sexual behavior was determined (about 5-6 weeks). Phase 3: individual monkeys were captured on two successive days per week; on the first day, monkeys were captured, restraincd, and returned to their home cage for subsequent videotaping $15 \mathrm{~min}$ later when doors between cages were opened to release females. This observation served as a preinjection baseline determination. The following day, monkeys were captured, restrained, and injected with 5 $\mu 1$ of peptide solution or vehicle. Pilot studies with $1.0 \mu \mathrm{g}$ OT revealed that behavioral effects noted between 15 and 30 min were absent at 60 $95 \mathrm{~min}$ after intracerebroventricular administration. Subsequent observations were videotaped and limited to a 15 -min interval that began when doors were opened between females and males 15 min after peptide injection.

Peptide administration. Concentrations of OT $(0.02-0.2 \mu \mathrm{g} / \mu \mathrm{l})$, OTA $(0.01 \mu \mathrm{g} / \mu \mathrm{l})$, and AVP $(0.1,1.0 \mu \mathrm{g} / \mu \mathrm{l})$ were prepared in buffered, sterile saline. Saline solution alone was used for vehicle injections. To study the interaction of OT and OTA, peptide concentrations were prepared for delivery in a single 5- $\mu$ injection. Fifteen minutes before behavioral testing, each monkey was rapidly removed from his home cage and gently hand restrained. The threaded stylette was removed from the guide cannula and replaced with a 30-gauge inner cannula. Using a Hamilton microsyringe, $5 \mu$ l of peptide solution was infused over a 60 sec interval. Patency of the cannula was determined by the free-flow of the injectate. Peptides were obtained from Peninsula Laboratories, Inc. (Belmont, CA).

Statistical analysis. For baseline analysis of status-related behavioral differences, repeated independent $t$ tests were used to separately compare the frequency and duration of various behavioral categories exhibited by dominant and subordinate monkeys. For the analysis of peptide effects, frequency and duration of each behavior were analyzed separately using two-way fixed factor ANOVAs for dose and social status. Dunnett's test comparisons $\left(t_{\mathrm{D}}\right)$ were performed to compare peptide effects against control values (Winer, 1971).

\section{Results}

Baseline measures. Assessment of the aggressive and sexual behavior exhibited by monkeys across the three phases of the study revealed remarkable stability, with dominant monkeys exhibiting significantly more aggressive $[F(1,18)=15.07 ; p<0.05]$ and sexual $[F(1,18)=8.54 ; p<0.05]$ inititatives than subordinate monkeys. No significant differences were detected in the frequencies (mean \pm 1 SEM) of aggressive (undisturbed phase, $2.67 \pm 0.77$; capture-adaptation phase, $2.70 \pm 0.45$; peptide injection phase, $2.0 \pm 0.51$ ) or sexual behaviors (undisturbed phase, $4.25 \pm 0.85$; capture-adaptation phase, $4.01 \pm 1.19$; peptide injection phase, $5.88 \pm 1.88$ ) exhibited by eight monkeys during the three baseline determination phases. Table 1 summarizes the behavior of dominant and subordinate monkeys observed during the preinjection phases of baseline data collection (eight observations per monkey). Pairs of male squirrel monkeys established reliable dominance relationships expressed as significant differences in the frequency of aggressive $(t=2.824 ; p<0.05)$, sexual $(t=2.285 ; p<0.05)$, but not associative behaviors. Social status based on behavioral differences was associated with significant differences in plasma testosterone concentration $(t=4.943 ; p<0.05$; Fig. 1, Table 1). During the peptide administration phase, intracerebroventricular administration of saline did not significantly affect aggressive and sexual behavior compared to behavior exhibited on the immediately preceding days when monkeys were captured but not injected. Consequently, data from the noninjected and saline injected trials have been combined as a single control condition for comparison with peptide treatment.

Peptide effects on monkey social behavior. Intracerebroventricular administration of OT $(0.1,1.0 \mu \mathrm{g})$ significantly affected both the aggressive and the nonaggressive social behavior of treated squirrel monkeys. Peptide effects depended on type of behavior, dose, and social status. OT $(0.1,1.0 \mu \mathrm{g})$ significantly increased the frequency of aggressive [threat, displace, grasp; $F(4,70)=5.822 ; p<0.05]$ and sexual initiatives (mounting and anogenital investigation; $F(4,70)=3.919 ; p<0.05$; Fig. 2 , Table 2]. Post hoc analysis revealed that increases in aggressive $(0.1$, $1.0 \mu \mathrm{g})$ and sexual behavior $(0.1 \mu \mathrm{g})$ were restricted to dominant monkeys. Decreases in time spent in the huddled-sitting posture 
Figure 1. The mean monthly body weights of four dominant (circles) and four subordinate (squares) monkeys collected between June 1989 and June 1990. Columns indicate the plasma testosterone concentrations for dominant (open columns) and subordinate (shaded columns) monkeys collected at various intervals during the course of the study.

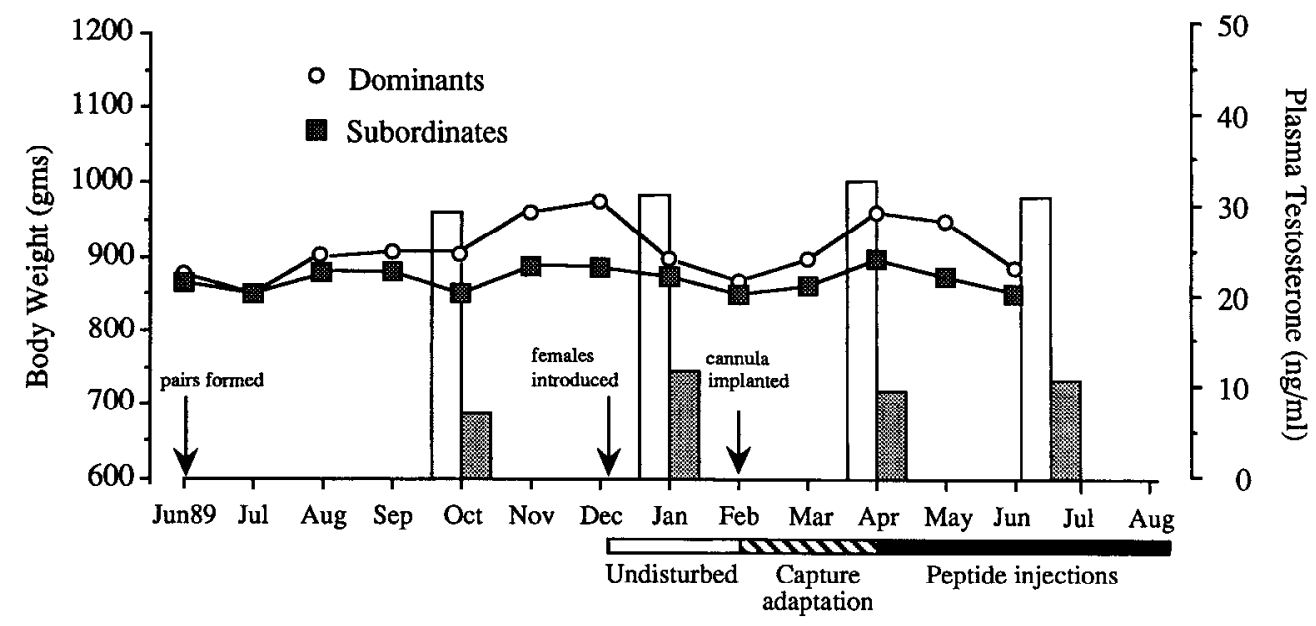

$=3.599 ; p<0.05]$ independent of social status, associated with a nonsignificant decrease in time spent in the huddled-sitting posture (Table 3). AVP did not affect the frequency of sexual behavior at the doses tested. Duration of stationary alert posture and eating and the frequency of grooming and marking were also unaffected by these doses (Table 3).

\section{Discussion}

Earlier studies in rodents have demonstrated that several of the behavioral effects of OT are dependent on the gonadal-steroid induction of OT receptors. To investigate whether a similar phenomenon might emerge in squirrel monkeys, we compared behavioral responses to OT in squirrel monkeys with environmentally determined differences in circulating testosterone. Pairhoused male squirrel monkeys developed quantitatively definable dominance relationships. Relatively high rates of aggressive and sexual initiatives by dominant compared to subordinate monkeys were associated with significantly higher plasma concentrations of testosterone. Central administration of OT increased the aggressive and sexual behavior of dominant but not subordinate monkeys. OT effects on aggressive and sexual behavior were blocked by the OT-selective antagonist OTA and were not mimicked by AVP. The enhanced sensitivity of dominant squirrel monkeys to the central effects of OT supports the

\begin{tabular}{lccl}
\hline \multicolumn{2}{l}{ Table 1. Status-related baseline behavioral and physiological differences } \\
Measure & Dominant monkeys & Subordinate monkeys & Significance \\
\hline Plasma testosterone $(\mathrm{ng} / \mathrm{ml})$ & $35.69 \pm 4.11$ & $13.33 \pm 1.93$ & $p<0.05$ \\
Frequency & $3.31 \pm 0.55$ & $1.63 \pm 0.60$ & $p<0.05$ \\
$\quad$ Agonistic & $2.84 \pm 0.73$ & $2.81 \pm 0.70$ & $\mathrm{NS}$ \\
Associative & $5.50 \pm 1.98$ & $0.91 \pm 0.31$ & $p<0.05$ \\
$\quad$ Sexual & $2.25 \pm 0.51$ & $1.25 \pm 0.25$ & $p<0.10$ \\
Marking & $12.56 \pm 1.21$ & $12.91 \pm 1.68$ & $\mathrm{NS}$ \\
$\quad$ Autogrooming & & & \\
Duration (in sec) & $118.19 \pm 17.29$ & $106.88 \pm 21.03$ & $\mathrm{NS}$ \\
$\quad$ Walking/patrolling & $319.75 \pm 49.75$ & $385.28 \pm 50.60$ & $\mathrm{NS}$ \\
$\quad$ Huddled sitting & $427.34 \pm 53.70$ & $442.38 \pm 44.00$ & $\mathrm{NS}$ \\
Stationary alert & $31.09 \pm 8.76$ & $75.88 \pm 23.87$ & $p<0.10$ \\
Foraging &
\end{tabular}

Data are from eight observations per monkey, four monkeys per status, and represent weekly observations collected following housing of female monkeys in cages adjacent to males. $p$ values refer to independent $t$ test comparisons. 
Aggressive Behavior (genital display, grasp or displacement)

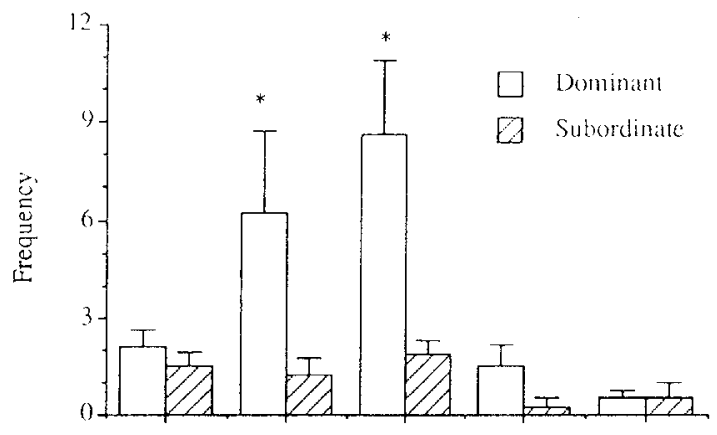

Sexual Behavior (ano-genital inspection or mounting of female)

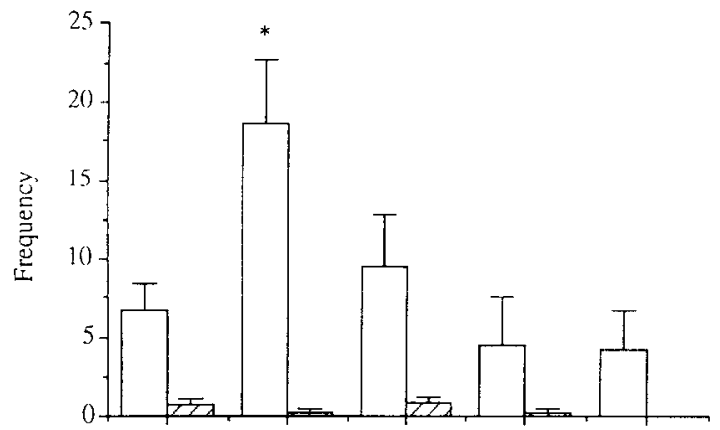

Associative Behavior (approach, touch, or huddle with partner)

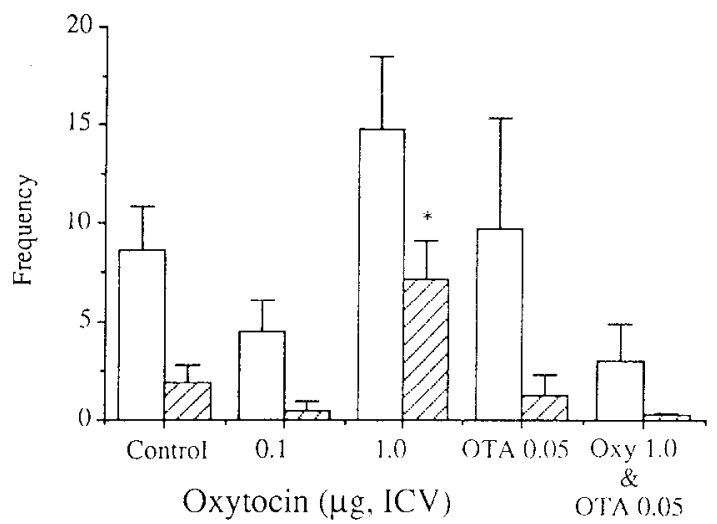

Figure 2. The frequency of aggressive (top), sexual (middle), and associative (bottom) behaviors exhibited by dominant (open columns) and subordinate (hatched columns) monkeys during 15-min observations beginning $15 \mathrm{~min}$ after intracerebroventricular administration of OT $(0.1,1.0 \mu \mathrm{g})$, OTA $(0.05 \mu \mathrm{g})$, or combined administration of OT $(1.0$ $\mu \mathrm{g})$ and OTA $(0.05 \mu \mathrm{g})$. Vertical lines at each column represent + 1 SEM; asterisks indicate $p<0.05$ for Dunnett's $t$ comparisons.

hypothesis that social status influences the behavioral expression of central OT release. Several possible mechanisms may account for these results.

The differential effects of OT may be related to significant differences in plasma testosterone measured in dominant and subordinate squirrel monkcys. In the present study, OT effects in the social group were recorded in the aggressive and sexual behavior of dominant monkeys and the marking behavior of subordinate monkeys. These behaviors have been shown to covary with a seasonal change in plasma testosterone concentrations, particularly in dominant male monkeys (Coe et al., 1985; Hennessey et al., 1978; Winslow and Miczek, 1988). A
Aggressive Behavior (genital display. grasp or displacement)

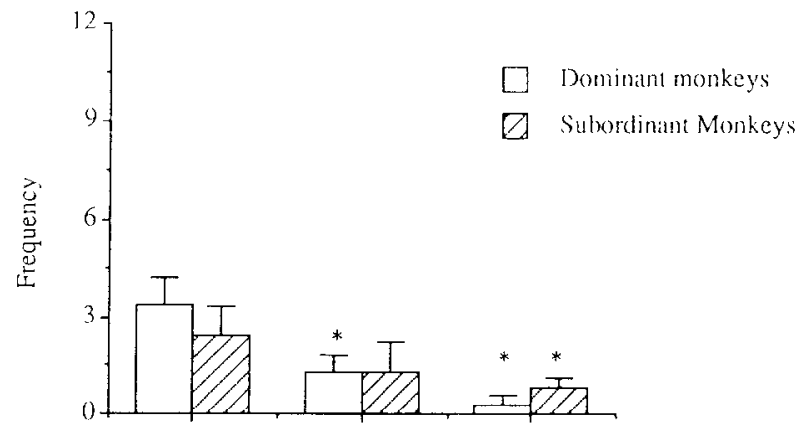

Sexual Behavior (ano-genital inspection or mounting of female)

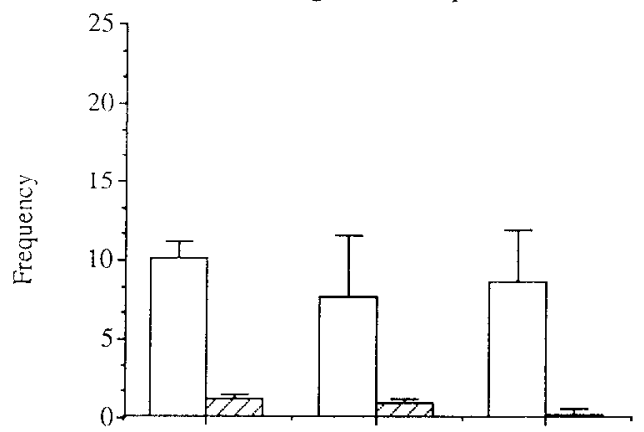

Associative Behavior (approach, touch, or huddle with partner)

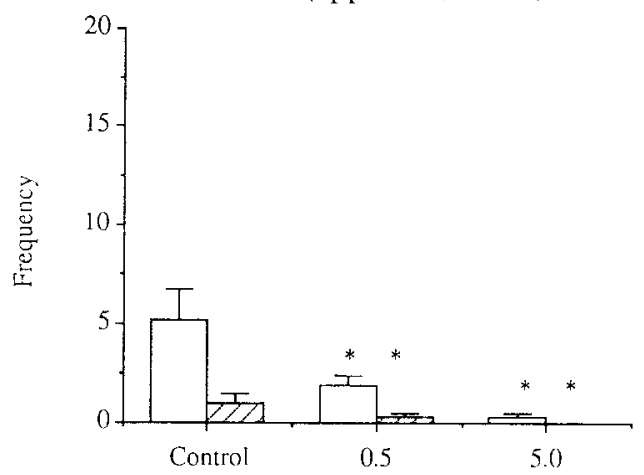

AVP $(\mu g . I C V)$

Figure 3. The frequency of aggressive (top), sexual (middle), and associative (bottom) behaviors exhibited by dominant (open columns) and subordinate (hatched columns) monkeys during 15-min observations beginning $15 \mathrm{~min}$ after intracerebroventricular administration of AVP $(0.5,5.0 \mu \mathrm{g})$. Vertical lines at each column represent $+1 \mathrm{SEM}$; asterisks indicate $p<0.05$ for Dunnett's $t$ comparisons.

role for OT in the expression of steroid-dependent sexual behavior in male rats (Arletti et al., 1985; Stoneham et al., 1985; Hughes et al., 1987) and rabbits (Melin and Kihlstrom, 1963) has previously been described. In the rat, several studies have reported that OT receptor density in the ventromedial nucleus of the hypothalamus and the bed nucleus of the stria terminalis (areas implicated in the mediation of sexual and maternal behavior) depend on gonadal hormone concentrations (De Kloct et al., 1986; Insel, 1986, 1990; Johnson et al., 1989; Tribollet et al., 1990). One potential explanation for the status-related differences in squirrel monkey response to OT is that dominant and subordinate monkeys with different concentrations of circulating testosterone may have different concentrations of OT receptors in brain. Binding studies investigating status related 


\begin{tabular}{|c|c|c|c|c|c|c|}
\hline Behavior & Status $^{a}$ & Control & $0.10 \mu \mathrm{g} \mathrm{OT}$ & $1.00 \mu \mathrm{g} \mathrm{OT}$ & $0.05 \mu \mathrm{g}$ OTA & $\mathrm{OTA}+\mathrm{OT}$ \\
\hline \multicolumn{7}{|l|}{ Frequency } \\
\hline Marking & $\begin{array}{l}\mathrm{D} \\
\mathrm{S}\end{array}$ & $\begin{array}{l}4.6 \pm 1.7 \\
1.6 \pm 0.5\end{array}$ & $\begin{array}{l}5.8 \pm 3.4 \\
0.3 \pm 0.3\end{array}$ & $\begin{array}{l}7.5 \pm 1.2 \\
8.8 \pm 2.7^{*}\end{array}$ & $\begin{array}{l}2.5 \pm 1.6 \\
4.3 \pm 1.9\end{array}$ & $\begin{array}{l}1.8 \pm 0.8 \\
1.8 \pm 1.4\end{array}$ \\
\hline Autogrooming & $\begin{array}{l}\mathrm{D} \\
\mathrm{S}\end{array}$ & $\begin{array}{l}10.6 \pm 1.8 \\
11.7 \pm 1.4\end{array}$ & $\begin{array}{r}15.0 \pm 2.4 \\
6.0 \pm 2.0\end{array}$ & $\begin{array}{l}19.1 \pm 2.1^{*} \\
18.1 \pm 3.9^{*}\end{array}$ & $\begin{array}{l}8.3 \pm 1.8 \\
9.3 \pm 3.9\end{array}$ & $\begin{array}{l}8.0 \pm 1.6 \\
2.8 \pm 1.1\end{array}$ \\
\hline \multicolumn{7}{|l|}{ Duration (in secs) } \\
\hline Walking/patrolling & $\begin{array}{l}\mathrm{D} \\
\mathrm{S}\end{array}$ & $\begin{array}{l}114.4 \pm 11.7 \\
134.6 \pm 38.9\end{array}$ & $\begin{array}{l}104.3 \pm 6.5 \\
249.8 \pm 96.9\end{array}$ & $\begin{array}{l}103.4 \pm 4.9 \\
104.4 \pm 37.5\end{array}$ & $\begin{aligned} 76.5 & \pm 13.7 \\
276.0 & \pm 121.1\end{aligned}$ & $\begin{aligned} 77.3 & \pm 11.1 \\
139.3 & \pm 100.4\end{aligned}$ \\
\hline Huddled sitting & $\begin{array}{l}\mathrm{D} \\
\mathrm{S}\end{array}$ & $\begin{array}{l}256.7 \pm 31.4 \\
372.6 \pm 61.3\end{array}$ & $\begin{aligned} 85.5 & \pm 53.0^{*} \\
185.5 & \pm 80.3\end{aligned}$ & $\begin{array}{l}232.1 \pm 37.4 \\
374.9 \pm 59.9\end{array}$ & $\begin{array}{l}401.3 \pm 72.9 \\
318.0 \pm 192.0\end{array}$ & $\begin{array}{l}534.0 \pm 98.5^{*} \\
408.3 \pm 196.6\end{array}$ \\
\hline Stationary alert & $\begin{array}{l}\mathrm{D} \\
\mathrm{S}\end{array}$ & $\begin{array}{l}307.1 \pm 25.6 \\
280.4 \pm 40.3\end{array}$ & $\begin{array}{l}450.8 \pm 69.8 \\
341.0 \pm 76.8\end{array}$ & $\begin{array}{l}338.4 \pm 45.9 \\
276.9 \pm 58.6\end{array}$ & $\begin{array}{l}314.0 \pm 76.3 \\
196.3 \pm 53.9\end{array}$ & $\begin{array}{l}189.5 \pm 57.8 \\
167.5 \pm 72.4\end{array}$ \\
\hline Foraging & $\begin{array}{l}\mathrm{D} \\
\mathrm{S}\end{array}$ & $\begin{array}{l}53.2 \pm 22.9 \\
14.2 \pm 6.7\end{array}$ & $\begin{array}{l}26.3 \pm 19.6 \\
47.5 \pm 25.3\end{array}$ & $\begin{array}{l}24.9 \pm 16.1 \\
16.0 \pm 28.8\end{array}$ & $\begin{array}{c}7.5 \pm 7.5 \\
15.0 \pm 11.9\end{array}$ & $\begin{array}{c}1.8 \pm 1.8 \\
36.0 \pm 22.0\end{array}$ \\
\hline
\end{tabular}

differences in brain OT receptors in the squirrel monkey are in progress. It is worth noting, however, that in the rat not all brain OT receptor fields are steroid sensitive (Insel, 1986; Tribollet et al., 1990); consequently, some behavioral effects of OT may not be influenced by gonadal correlates of social status. Indeed, OT effects on autogrooming appeared equally potent in both dominant and subordinate monkeys and thus may be subserved by OT receptors in a non-steroid-dependent target field.

Individual differences in the effects of OT on behavior may reflect behavioral constraints associated with the contingencies of social organization. Such an explanation is suggested by the finding that, though subordinate monkeys did not express changes in the frequency of aggressive and sexual behaviors comparable to dominant monkeys, the frequency of potentially less provocative associative and marking behaviors was selectively increased. Status-dependent differences in the effects of drugs from a variety of drug classes have been previously reported (Miczek and Gold, 1983; Raleigh et al., 1985; Winslow and Miczek, 1985). For example, alcohol effects on aggressive behavior were only observed in dominant monkeys living in social groups, and these effects were exaggerated during the mating season when plasma testosterone levels were dramatically increased (Winslow and Miczek, 1988). However, in a subsequent study, ex- ogenous elevation of plasma testosterone concentrations during the nonmating season to mating season levels did not significantly modify the behavior of either dominant or subordinate monkeys, though the sensitivity to alcohol was affected in both status groups. The behavior of testosterone-treated subordinates was also unchanged up to 5-7 weeks after removal of the dominant monkey from the social group (Winslow et al., 1988). A similar recalcitrance to subordinate members of talapoin monkey groups (Eberhart et al., 1985). These findings suggest that, though testosterone may modulate aggressive and sexual initiatives, social contingencies and prior experience play a preeminent role. The differential effects of OT may similarly reflect status-related differences in social contingencies or the consequence of prior experience.

The failure of OTA to affect social behavior suggests that OT may have a limited physiological role in the maintenance of these behaviors. This negative interpretation may be limited by a floor effect, or the paucity of social behavior may have precluded our observing further declines. In addition, OTA may have an unusual time course for interrupting physiological processes. In a related study on sexual behavior in female rats, OTA effects were only observed $2-4 \mathrm{hr}$ after intracerebroventricular administration (Witt and Insel, 1991). Our focus on the first 30

\begin{tabular}{lcccc}
\hline \multicolumn{2}{l}{ Table 3. Behavioral effects of AVP } & & & \\
& & & & \\
Behavior & Status $^{a}$ & Control & $0.05 \mu \mathrm{g}$ AVP & $5.0 \mu \mathrm{g}$ AVP \\
\hline Frequency & & & & \\
Marking & $\mathrm{D}$ & $7.0 \pm 4.2$ & $1.5 \pm 0.9$ & $8.5 \pm 4.2$ \\
& $\mathrm{~S}$ & $1.3 \pm 0.5$ & $2.0 \pm 0.7$ & $2.8 \pm 1.0$ \\
Autogrooming & $\mathrm{D}$ & $12.6 \pm 2.8$ & $11.8 \pm 4.5$ & $16.0 \pm 5.2$ \\
& $\mathrm{~S}$ & $12.8 \pm 2.1$ & $10.0 \pm 1.1$ & $12.8 \pm 4.6$ \\
Duration (in secs) & & & & \\
Walking/patroling & $\mathrm{D}$ & $116.6 \pm 19.8$ & $176.0 \pm 51.89^{*}$ & $179.8 \pm 15.15^{*}$ \\
& $\mathrm{~S}$ & $108.1 \pm 35.9$ & $254.5 \pm 88.9^{*}$ & $259.3 \pm 88.84^{*}$ \\
Huddled sitting & $\mathrm{D}$ & $292.4 \pm 52.9$ & $121.5 \pm 58.0$ & $56.0 \pm 32.3$ \\
& $\mathrm{~S}$ & $346.4 \pm 100.8$ & $267.8 \pm 140.2$ & $371.8 \pm 186.5$ \\
Stationary alert & $\mathrm{D}$ & $265.1 \pm 36.5$ & $296.5 \pm 68.2$ & $458.8 \pm 58.8$ \\
& $\mathrm{~S}$ & $330.8 \pm 73.6$ & $279.3 \pm 63.1$ & $232.3 \pm 84.7$ \\
Foraging & $\mathrm{D}$ & $12.8 \pm 6.4$ & $10.8 \pm 7.4$ & $47.3 \pm 44.6$ \\
& $\mathrm{~S}$ & $4.6 \pm 3.5$ & $20.5 \pm 17.6$ & $3.5 \pm 2.4$ \\
\hline
\end{tabular}

a $\mathrm{D}$, dominant; $\mathrm{S}$, subordinate.

${ }^{*} p<0.05$ for Dunnett's $t$ test comparisons of treatments against control. 
min after peptide administration may have thus prevented observation of intrinsic OTA effects. Nevertheless, OTA's blockade of exogenous OT demonstrates that OT's effects were mediated by the OT receptor.

In contrast to OT, the effects of AVP did not depend on social status. The different behavioral profiles of OT and AVP indicate peptide specificity in spite of the relative absence of selectivity of these peptides in receptor binding in vitro(Elands et al., 1987). Social and aggressive initiatives were reduced, and walking/ patrolling increased, suggesting nonspecific effects on motor activity. These findings differ from earlier studies of central administration of AVP to hamsters (Ferris et al., 1984). In this and subsequent studies (Albers and Ferris, 1985, 1986; Albers et al., 1986, 1988), Ferris and coworkers convincingly demonstrated stimulation of flank marking following intrahypothalamic administration of AVP and inhibition of marking following administration of AVP antagonists. Flank marking appears to be an important element in the behavioral repertoire associated with establishing and maintaining social dominance in the hamster (Ferris et al., 1987). In the present studies, intracerebroventricular AVP did not significantly affect the marking behavior of squirrel monkeys and reduced the aggressive behavior of both dominant and subordinate monkeys. These changes did not appear to be associated with changes in social status, because dominant monkeys continued to monopolize interactions with females. Differences in the effects of AVP on squirrel monkcy and hamster aggressive behavior may reflect different reproductive strategies in the two species. For example, unlike hamsters, squirrel monkeys do not defend fixed territories, and the marking behavior appears to function primarily to communicate reproductive status (Thorington, 1968; Mitchell et al., 1991).

In summary, consistent with previously reported findings in male rats, OT increased the frequency of sexual initiatives exhibited by male squirrel monkeys. The increased frequency of aggressive behavior reported here has not been previously described in male rodents and may reflect important species differences in social organization. An important qualification to OT's behavioral effects is the influence of social status. Subordinate squirrel monkeys did not show increases in either sexual or aggressive behavior at any of the doses tested. The statusrelated effects of OT may depend on gonadal hormone differcnces measured between dominant and subordinate monkeys, or the conditioned behavioral profile defined by the dominance relationship in established groups of primates. In preliminary studies, we have also detected OT induced increases in plasma testosterone that do not depend on the social status of the treated monkey. In contrast to OT, AVP effects did not depend on social status and appeared to be related to arousal. The data support a selective role for OT in the mediation of social interactions between adult male squirrel monkeys and demonstrate that these effects may be sensitive to the constraints of social experience.

\section{References}

Albers HE, Ferris CF (1985) Behavioral effects of vasopressin and oxytocin within the medial preoptic area of the golden hamster. Regul Peptides 12:257-260.

Albers HE, Ferris CF (1986) Role of the flank gland in vasopressin induced scent marking behavior in the hamster. Brain Res Bull 17: 387-389.

Albers HE, Pollock J, Simmons WH, Ferris CF (1986) A V1-like receptor mediates vasopressin-induced flank marking behavior in hamster hypothalamus. J Neurosci 6:2085-2089.
Albers HE, Liou SY, Ferris CF (1988) Testosterone alters the behavioral response of the medial preoptic-anterior hypothalamus to microinjection of arginine vasopressin in the hamster. Brain Res 456: 382-386.

Altman J (1974) Observational study of behavior: sampling methods. Behavior 49:227-267.

Arletti R, Bazzani C, Castelli M, Bertolini A (1985) Oxytocin improves male copulatory performance in rats. Horm Behav 19:14-20.

Bluthe RM, Schoenen J, Dantzer R (1990) Androgen-dependent vasopressinergic neurons are involved in social recognition in rats. Brain Res 519:150-157.

Burbach JPH, Adan RAH, van Tol HHM, Verbeek MAE, Axelson JF, van Leeuwen FW, Beekman JM, Ah G (1990) Regulation of the rat oxytocin gene by estradiol. J Neuroendocrinol 2:633-639.

Caldwell JD, Prange AJ Jr, Pedersen CA (1986) Oxytocin facilitates the sexual receptivity of estrogen-treated female rats. Neuropeptides $7: 175-189$.

Caldwell JD, Brooks PJ, Jirikowski GF, Barakat AS, Lund PK, Pedersen CA (1989) Estrogen alters oxytocin mRNA levels in the preoptic area. J Neuroendocrinol 1:1-7.

Coe CL, Mendoza SP, Levine S (1979) Social status constrains the stress response in the squirrel monkey. Physiol Behav 23:633-638.

Coe CL, Smith ER, Levine S (1985) The endocrine system of the squirrel monkey. In: Handbook of squirrel monkey research (Rosenblum LA, Coe CL, eds), pp 191-218. New York: Plenum.

Coirini H, Johnson AE, McEwen BS (1989) Estradiol modulation of oxytocin binding in the ventromedial hypothalamic nucleus of male and female rats. Neuroendocrinology 50:193-198.

De Kloet ER, Voorhius DAM, Boschma Y, Elands J (1986) Estradiol modulates density of putative "oxytocin receptors" in discrete rat brain regions. Neuroendocrinology 44:415-421.

DeVries GJ, Buijs RM, VanLeeuwen FW, Caffe AR, Swaab DF (1985) The vasopressinergic innervation of the brain in normal and castrated rats. J Comp Neurol 233:236-254.

Dornan WA, Malsbury CW (1989) Neuropeptides and male sexual behavior. Neurosci Biobehav Rev 13:1-15.

Drago F, Pedersen CA, Caldwell JD, Prange AJ (1986) Oxytocin potently enhances novelty-induced grooming behavior in the rat. Brain Res 368:287-295.

Eberhart JA, Yodingyuad U, Keverne EB (1985) Subordination in male talapoin monkeys lowers sexual behavior in the absence of dominants. Physiol Behav 35:673-677.

Elands J, Barberis C, Jard S, Tribollet E, Dreifuss J, Bankowski K, Manning M, Sawyer W (1987) ${ }^{17}$ I-labcllcd $d\left(\mathrm{CH}_{2}\right)_{5}\left[\mathrm{Tyr}(\mathbf{M c})^{2}, \mathrm{Thr}^{4}\right.$, Tyr- $\mathrm{NH}_{2}{ }^{9}$ ] OVT: a selective oxytocin receptor ligand. Eur J Pharm 147:197-207.

Fahrbach SE, Morrell JI, Pfaff DW (1984) Oxytocin induction of shortlatency maternal behavior in nulliparous, estrogen-primed female rats. Horm Behav 18:267-286.

Ferris CF, Albers HE, Wesolowski SM, Goldman BD, Luman SE (1984) Vasopressin injected into the hypothalamus triggers a stereotypic behavior in golden hamsters. Science 224:521-523.

Ferris CF, Axelson JF, Shinto LH, Albers HE (1987) Scent marking and the maintenance of dominant/subordinate status in male golden hamsters. Physiol Behav 40:661-664.

Gergen JA, MacLean PD (1962) A stereotaxic atlas of the squirrel monkey's brain (Saimiri sciureus). Bethesda, MD: U.S. Government Printing Office.

Gorzalka BB, Lester GLL (1987) Oxytocin-induced facilitation of lordosis behaviour in rats is progesterone-dependent. Neuropeptides 10 : 55-65.

Hennessey GG, Coe CL, Mendoza SL, Lowe EL, Levine S (1978) Scent-marking and olfactory investigatory behavior in the squirrel monkey (Saimiri sciureus). Behav Biol 24:57-67.

Hopf S, Hartmann-Weisner E, Kuhlmorgen B, Mayer S (1974) The behavioral repertoire of the squirrel monkey (Saimiri). Folia Primatol (Basel) 21:225-249.

Hughes AM, Everitt BJ, Lightman SL, Todd K (1987) Oxytocin in the central nervous system and sexual behavior in male rats. Brain Res 414:133-137.

Insel TR (1986) Postpartum increases in brain oxytocin binding. Neuroendocrinology 44:515-518.

Insel TR (1990) Regional changes in brain oxytocin receptors postpartum: time-course and relationship to maternal behavior. J Neuroendocrinol 2:1-7.

Johnson AE, Coirini H, McEwen BS, Insel TR (1989) Testosterone 
modulates oxytocin binding in the hypothalamus of castrated male rats. Neuroendocrinology 50:199-203.

Kendrick KM, Keverne EB, Baldwin BA (1987) Intracerebroventricular oxytocin stimulates maternal behaviour in the sheep. Neuroendocrinology 46:56-61.

Kovacs GL (1986) Oxytocin and behavior. In: Current topics in neuroendocrinology (Ganter D, Pfaff DW, Burbach PH, eds), pp 91-120. Berlin: Springer.

Melin P, Kihlstrom JE (1963) Influence of oxytocin on sexual behavior in male rabbits. Endocrinology 73:433-435.

Mendoza SP, Lowe EL, Davidson JM, Levine S (1978) Annual cyclicity in the squirrel monkey (Saimiri sciureus): the relationship between testosterone, fatting, and sexual behavior. Horm Behav 11:295-303.

Miczek KA, Gold LH (1983) Ethological analysis of amphetamine action on social behavior in squirrel monkeys (Saimiri sciureus). In: Ethopharmacology: primate models of neuropsychiatric disorders (Miczek KA, ed), pp 137-155. New York: Liss.

Mitchell CL, Boinski S, van Schaik CP (1991) Competitive regimes and female bonding in two species of squirrel monkeys (Saimiri oerstedi and $S$. sciureus). Behav Ecol Sociobiol 28:55-60.

Pedersen CA, Prange AJ (1979) Induction of maternal behavior in virgin rats after intracerebroventricular administration of oxytocin. Proc Natl Acad Sci USA 756:6661-6665.

Pliskin S, Johnson AE, Ball GF (1989) Changes in oxytocin binding are correlated with cyclic fluctuations in ovarian hormone levels. Soc Neurosci Abstr 15:435.13.

Raleigh MJ, Brammer GL, McGuire MT, Yuwiler A (1985) Dominant social status facilitates the behavioral effects of serotonergic agonists. Brain Res 348:274-282.

Stoneham MD, Everitt BJ, Hansen S, Lightman SL, Todd K (1985) Oxytocin and sexual behavior in the male rat and rabbit. J Endocrinol 107:97-106.

Thorington RW (1968) Observations of squirrel monkeys in a tropical forest. In: The squirrel monkey (Rosenblum LA, Cooper RW, eds), pp 69-85. New York: Academic.

Tribollet E, Audiger S, Dubois-Dauphin M, Dreifus JJ (1990) Gonadal steroids regulate oxytocin reccptors but not vassopressin receptors in the brain of male and female rats. An autoradiographic study. Brain Res 511:129-140.

Winer BJ (1971) Statistical principles in experimental design, 2d ed. New York: McGraw-Hill.

Winslow JT, Miczek KA (1985) Social status as determinant of alcohol effects on aggressive behavior in squirrel monkeys (Saimiri sciureus). Psychopharmacology 85:167-172.

Winslow JT, Miczek KA (1988) Androgen dependency of alcohol effects on aggressive behavior: a seasonal rhythm in high-ranking squirrel monkeys. Psychopharmacology 95:92-98.

Winslow JT, Ellingboe J, Miczek KA (1988) Effects of aicohol on aggressive behavior in squirrel monkeys: influence of testosterone and social context. Psychopharmacology 95:356-363.

Witt DM, Insel TR (1991) A sclcctivc oxytocin antagonist attenuates progesterone facilitation of female sexual behavior. Endocrinology, in press. 